Check for updates

The BMJ

fgodlee@bmi.com Follow Fiona on Twitter @fgodlee

Cite this as: BMJ 2021;374:n1721 http://dx.doi.org/10.1136/bmj.n1721 Published: 08 July 2021

\title{
Covid 19: We need a full open independent investigation into its origins
}

\section{Fiona Godlee editor in chief}

When news first broke that a contagious and deadly new virus had emerged in Wuhan, many were struck by the coincidence of the city being the home of one of the world's top virus research laboratories. But any suggestion that the virus originated in a laboratory was quickly labelled a conspiracy theory, dismissed by mainstream media, and even banned from Facebook. Donald Trump's support helped the theory on its way to being something that no progressive thinking person could entertain.

But, as Paul Thacker explains (doi:10.1136/bmj.n1656), ${ }^{1}$ suppression of the lab leak theory was not based on any clear evaluation of the science. Indeed, it happened despite no good counter-evidence for the alternative: natural spillover from animals to humans. Instead the lab leak theory sank under the weight of a concerted campaign by heavily conflicted scientists, leading to a "year of biased, failed reporting" by science journalists and journals. Now, thanks to the seismic shift in US politics and some dogged and fearless journalism, the theory is emerging from the shadows into mainstream public debate. We don't know which theory is right, but a lab leak is plausible and worthy of serious inquiry.

Meanwhile the fight against the virus continues around the world, with varying success (doi:10.1136/bmj.n1724, doi:10.1136/bmj.n1686). ${ }^{23}$ Despite cases in the UK rising exponentially, the government said it will lift all restrictions on 19 July (doi:10.1136/bmj.n1698). ${ }^{4}$ Trish Greenhalgh calls this a "colossal natural experiment which will put wave three of the pandemic into a super-exponential growth phase"

(https://blogs.bmj.com/bmj/2021/07/06/trishgreenhalgh-freedom-day-but-at-what-cost). ${ }^{5}$ The nature of this crisis is virological not economic, she writes. We can't grow ourselves out of it (doi:10.1136/bmj.n1681). ${ }^{6}$ Vaccination has weakened but not cut the link between infection and hospital admission, and high caseloads increase the risk of variants that are resistant to vaccines. Long covid is a growing concern

(https://blogs.bmj.com/bmj/2021/07/o6/we-musttake-long-covid-into-account-when-easing-covid-restrictions), ${ }^{7}$ though substantially under-reported in GP records (doi:10.1136/bmj.n1685). ${ }^{8}$ Young people make up an increasing proportion of those experiencing longer term illness, prompting calls to vaccinate children over the age of 12

(https://blogs.bmj.com/bmj/2021/07/06/we-shouldshift-our-focus-from-covid-19-mortality-to-morbidityparticularly-in-children). ${ }^{9}$

The mood among our political leaders is that we should all now take personal responsibility, neatly releasing them from doing their bit to limit transmission (https://blogs.bmj.com/bmj/2021/o6/29/after-restriction-why-the-public-can-only-fulfill-its-responsibilities-if-the-government-fulfills-theirs). ${ }^{10}$ The chaos and waste that has been NHS Test and Trace show no sign of abating, with the government refusing to properly support people who need to self-isolate and slow to expand the case definition to ensure that those who are most infectious get tested (doi:10.1136/bmj.n1625). ${ }^{11}$ While dropping almost all legal requirements, the government has, however, decided to impose one new legal stricture, that care workers must be vaccinated: an "unnecessary, disproportionate, and misguided" decision (doi:10.1136/bmj.n1684), ${ }^{12}$ when professionalisation and registration of care workers would do so much more good.

Does it matter how the virus originated? To prevent future pandemics, the world will need to tackle risks from all sources, whether from natural spillover or laboratory mishaps. That means tighter controls on wildlife farming and markets and greatly improved biosafety in research. But we still need to know how this worst in a century pandemic occurred, and for this we need a full, open, and independent investigation.

1 Thacker PD. The covid-19 lab leak hypothesis: did the media fall victim to a misinformation campaign?BMJ2021;374:n1656.

2 Taylor L. Covid-19: Vaccine corruption allegations spark protests across Brazil. BMJ 2021;374:n1724doi: 10.1136/bmj.n1724

3 Griffin S. Covid-19: Millions could be offered booster vaccinations from September. BMJ2021;374:n1686. doi: 10.1136/bmj.n1686 pmid: 34215593

4 Rimmer A. Covid-19: Doctors criticise government's plan to make mask wearing a personal choice. BMJ2021;374:n1717doi: 10.1136/bmj.n1717.

5 Greenhalgh T. Freedom Day, but at what cost? BMJ Opinion. 6 Jul 2021. https://blogs.bmj.com/bmi/2021/07/06/trish-greenhalgh-freedom-day-butat-what-cost.

6 Greenhalgh T. Health and wealth in pandemic times: not a zero sum game. BMJ 2021;374:n1681. doi: 10.1136/bmj.n1681 pmid: 34226177

7 Sherwood O, Whitehead K, Edwards S, Davies H. We must take long covid into account when easing covid restrictions. BMJ Opinion. 6 Jul 2021 https://blogs.bmj.com/bmj/2021/07/06/we-must-take-long-covid-into-account-when-easing-covid-restrictions

8 Wise J. Covid-19: Long covid cases are underreported in GP records, research suggests. BMJ 2021;374:n1685. doi: 10.1136/bmj.n1685 pmid: 34215626

9 Friston KJ, Costello A. We should shift our focus from covid-19 mortality to morbidity, particularly in children. BMJ Opinion. 6 Jul 2021. https://blogs.bmj.com/bmj/2021/07/06/we-should-shift-our-focus-fromcovid-19-mortality-to-morbidity-particularly-in-children.

10 Reicher S. After restriction: why the public can only fulfill its responsibilities if the government fulfills theirs. BMJ Opinion. 29 Jun 2021. https://blogs.bmj.com/bmj/2021/06/29/after-restriction-why-the-publiccan-only-fulfill-its-responsibilities-if-the-government-fulfills-theirs.

11 Crozier A, Dunning J, Rajan S, Semple MG, Buchan IE. Could expanding the covid-19 case definition improve the UK's pandemic response?BMJ 2021;374:n1625. doi: 10.1136/bmj.n1625 pmid: 34193527

12 Hayes L, Pollock AM. Mandatory covid-19 vaccination for care home workers. BMJ2021;374:n1684.

This article is made freely available for use in accordance with BMJ's website terms and conditions for the duration of the covid-19 pandemic or until otherwise determined by BMJ. You may use, download and print the article for any lawful, 
non-commercial purpose (including text and data mining) provided that all copyright notices and trade marks are retained. 